\title{
Mice made from induced stem cells
}

\section{iPS 細胞からマウス個体を作製}

David Cyranoski Nature Vol.460(560)/30 July 2009

人工多能性幹細胞（iPS 細胞）から、実際に完全な哺乳類個体を作製することに成功した。

中国の 2 組の研究チームが iPS 細胞から 生きたマウスを作り出し、iPS 細胞から生 物の完全な個体を発生させることができる のかどうかという、かねてからの疑問に答 えを出した。

2006 年に京都大学の山中伸弥が初め て iPS 細胞 ${ }^{1}$ を作り出して以来、iPS 細胞 からも本当の胚性幹細胞（ES 細胞）と同 じように完全な哺乳類の個体が作れるのか どうかが研究界の疑問となっていた。今回、 少なくともマウスに関しては、その答えが イエスだというこうことが、Nature 2009 年 9 月 3 日号 ${ }^{2}$ とCell Stem Cell 2009 年 8 月号 ${ }^{3}$ に発表された論文で示された。

Nature の論文では、動物のクローンを 研究している動物研究所 (中国、北京) の周琪 (Zhou Qi) と上海交通大学の曾 凡ー (Zeng Fanyi) らが、まずウイルス ベクターを使ってマウスの線維芽細胞に 4 つの遺伝子を導入するという山中と同じ方 法で、iPS 細胞を作った。研究チームの狙 いは、導入した因子が細胞を再プログラ ム化することにより、その細胞を体内のあ らゆる種類の細胞に分化できるようにする ことだった。

再プログラム化がうまくいったかどうか を確かめるために周と曾が最初に行った のは、iPS 細胞が胚性幹細胞（ES 細胞） と同じ表面マーカーをもっているかどうか 分析するなどの標準的な検査だった。次 に、研究チームは、初期の受精胚の 2 細 胞を融合させることによって「4 倍体」胚 を作製した（右上の図を参照）。４倍体胚 は、胎盤と、発生に必要な細胞は発生す
るが、将来個体になる胚細胞は発生しな い。それは、いうなれば、運転手のいな い自動車のようなものである。

この 4 倍体胚に作製した iPS 細胞を移 植すると、発生が始まった（4 倍体胚補完 法)。続いて、発生が進行している胚を代 理母に移植したところ、20日後に子マウ スが生まれた。そのマウスは、iPS 細胞の 作製に使ったマウスと同じく黒い体毛をし ており、4 倍体胚の作製に使った白いマウ スとは明らかに違う色だった。「小小 (シャ オシャオ)」と名付けられたそのマウスは、 DNA 検査の結果、iPS 細胞由来であるこ とが確認された。

マサチューセッツ工科大学 (米国、ケン ブリッジ）でクローン作製の研究を行って いる Rudolf Jaenisch は、2007 年に同じ 実験をしようとしたが、後期から先の胚を 作り出すことができなかった ${ }^{4}$ 。Jaenisch は自分たちの失敗について「2 通りの可能 性が考えられます」と語る。「iPS 細胞に多 能性がないためにできなかったのか、我々 の努力が足りなかったのかのどちらかで しょう。前者なら興味深いことになったか もしれませんが、後者が原因でしょうね」。

中国の研究チームの努力は Jaenisch ら を上回っていた。培地を調整し、最初の マウスが生まれるまで発生中の胚を 250 個分析していたのだ。

論文には 27 匹が生まれたと書かれてい るが、最高の細胞株と最適の実験条件で 行っても、注入した胚 624 個から生まれ たのは 22 匹で、成功率は $3.5 \%$ だった。 曾によれば、高い死亡率が認められ、わ

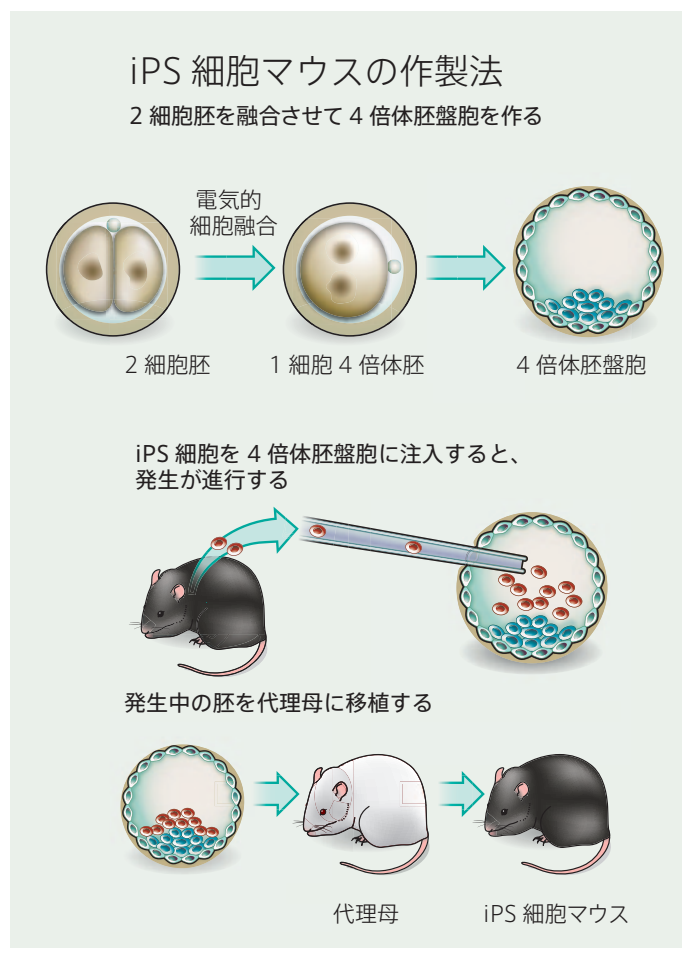

ずか 2 日で死んでしまったマウスのほか、 詳細は伏せられているが、体に異常がみ られるものもいたという。

その一方で、一部のマウスは最も基本 的な健康検査に合格している。つまり、交 尾させた 12 匹すべてが子どもを産み、生 まれた子どもに異常がなかったのだ。研 究チームによれば、現在、2 代目のマウ スが数百匹おり、3 代目も 100 匹を超え ているという。組織的な検査を行ったわけ ではないものの、これらのマウスに腫瘍 は認められていない。

Cell Stem Cell 掲載論文の研究チームの リーダー、北京生命科学研究所の高紹栄 
（Gao Shaorong）も、成功には辛抱強 さが必要だと考えている。曾、周らと同じ 基本技術を使った高のグループは、4 倍 体の補完胚 187 個にiPS 細胞を導入し、 生きたマウスを 2 匹だけ得ることができた (効率 1.1\%)。ただし、1 匹は間もなく 死んでしまった。「そうした細胞株が得ら れる確率は低いのですが、根気強く実験 しました」と高は語る。高らは現在、生存 したマウスを交配させようとしている。

現在、両グループが解明しようとしてい るのは、体の異常、高い死亡率、低い効率、 そして多くのiPS 細胞株がマウスの作製に 適していないらしいという現実が、iPS 細 胞とES 細胞とのどういった違いによるも のなのかということだ。曾と周は、1つの 答えとして、タイミングが重要であること を発見した。短期間 (14 日間) でコロニー を形成したiPS 細胞ではうまくいくが、コ ロニーの形成に20 日または 36 日かかっ た細胞は使えなかったというのだ。高は、 少なくとも効率の低さに関しては、「再プ ログラム化の異常」が原因なのではない かと考えている。
こうしたマウスでの研究は、ヒトの ES 細胞とiPS 細胞との根本的な差を解明する うえでもきっと役に立つだろう。既に7月、 カリフォルニア大学口サンゼルス校 (米国) の研究チームは、通常の多能性検査に合 格したヒトiPS 細胞が、遺伝子の発現の 点で、ヒト ES 細胞と異なっていることを 発表している ${ }^{5}$ 。このチームのメンバー、 Kathrin Plath は、「iPS 細胞にはES 細胞 と比べて一長一短がありそうですが、今の 時点ではまだ、我々は、その答えにたどり ついていないでしょう」という。今回の中 国の研究については、ヒトの胚では 4 倍 体補完法を行うことができないので、iPS 細胞の臨床応用に大きな意義をもつもの ではない、と同僚の William Lowry は付 け加えている。

周と曾は、iPS マウスを従来法によるク ローンマウスと比較することや、成体マウ スでも同じ実験ができることを証明するこ となど、新たな道を模索している。（どち らの研究でも、iPS 細胞の作製に使われ た線維芽細胞は、後期胚に由来していた。) これは、成体の DNA を再プログラム化
して遺伝的に同じ個体を作り出すもので、 実質的に成体の哺乳類の新しいクローン 作製法となるだろう。それは、異常の発 生が従来のクローン作製法よりも少ない 簡単な方法と考えられ、ヒトのクローンを 作製するツールとして、倫理を無視しても クローン作製を行いたい者たちの関心を よぶかもしれない。最近、中国では、こ うしたクローン作製を禁止する法律が強化 された 6

「この技術が『再プログラム化を解明す るための重要なモデル』として利用できる ようになることを望んでいるのです。けっ して、iPS 細胞を使ってクローン人間を作 り出すための第一歩にすることをめざして いるわけではないのです」と、周は語って いる。(小林盛方 訳)

\footnotetext{
1. Takahashi, K. \& Yamanaka, S. Cell 126, 663-676 (2006).

2. Zhao, X.-Y.et al. Nature 461, 86-90 (2009).

3. Kang, L. et al. Cell Stem Cell 5135 - 138 (2009).

4. Wernig, M. et al. Nature 448, 318-324 (2007).

5. Chin, M. H. et al. Cell Stem Cell 5, 111-123 (2009).

6. Cyranoski, D. Nature 459, 146-147 (2009).
} 